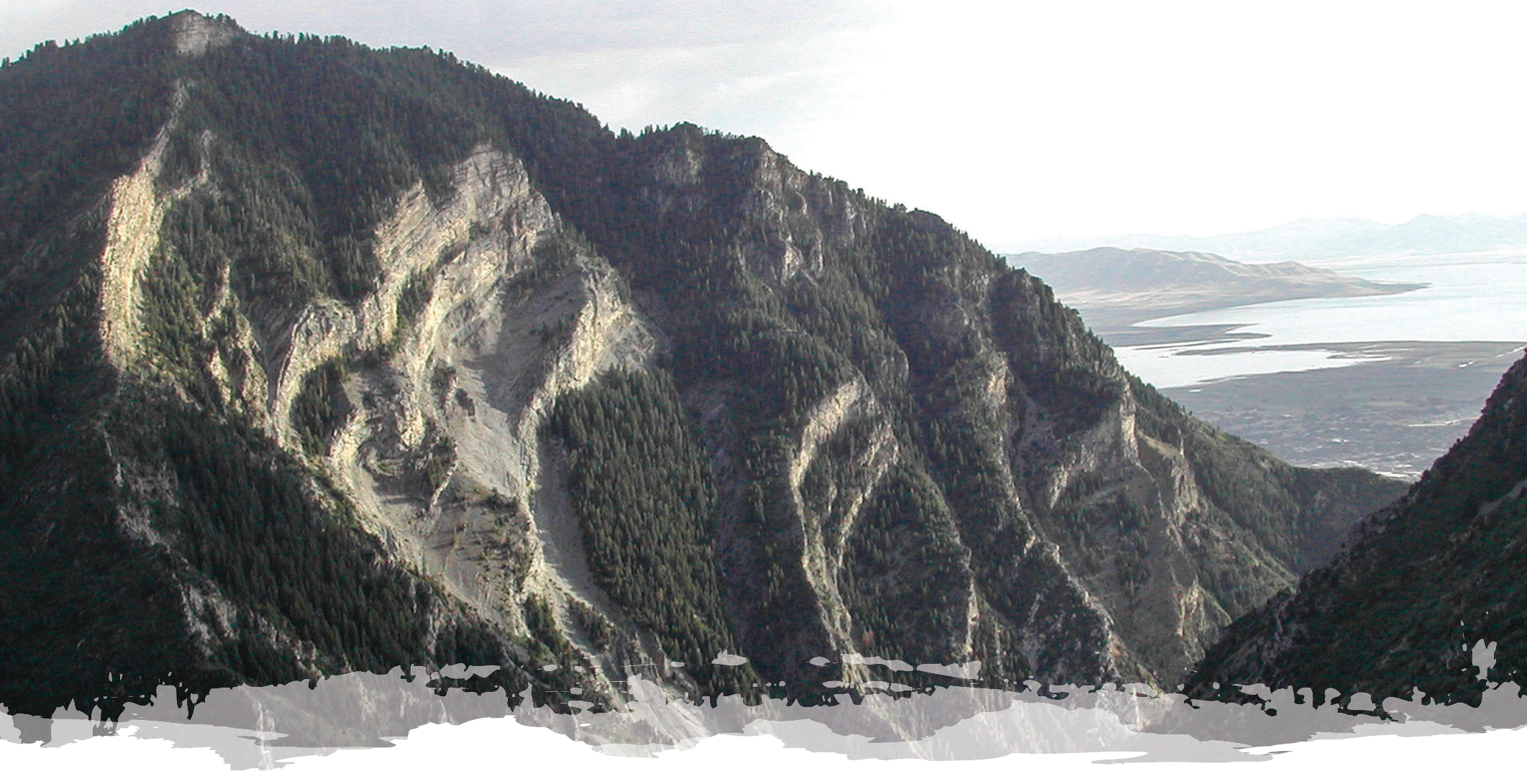

\title{
Rock Canyon near Provo, Utah County: A Geologic Field Laboratory
}

Bart J. Kowallis and Laura C. Wald

Department of Geological Sciences, Brigham Young University

Provo, Utah 84604

bkowallis@byu.edu

\section{Utah Geosites \\ 2019}

Utah Geological Association Publication 48

M. Milligan, R.F. Biek, P. Inkenbrandt, and P. Nielsen, editors

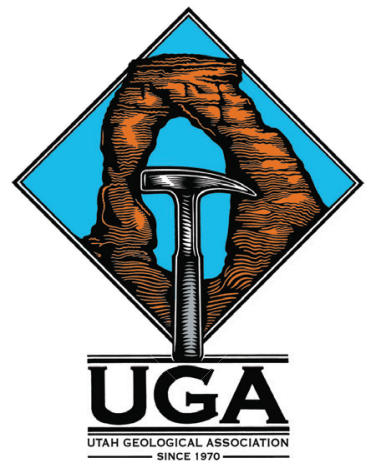




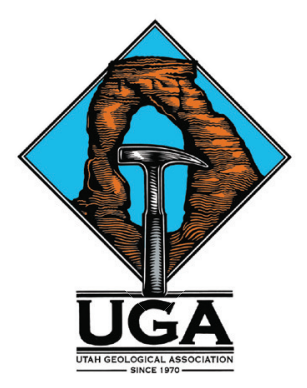

\section{Utah Geosites} 2019

\section{Utah Geological Association Publication 48}

M. Milligan, R.F. Biek, P. Inkenbrandt, and P. Nielsen, editors

Utah Geosites showcases some of Utah's spectacular geology, both little-known localities and sites seen by visitors to Utah's many national and state parks and monuments. The geosites reflect the interests of the many volunteers who wrote to share some of their favorite geologic sites. The list is eclectic and far from complete, and we hope that additional geosites will be added in the coming years. The Utah Geological Survey also maintains a list of geosites https://geology.utah.gov/apps/geosights/index.htm.

We thank the many authors for their geosite contributions, Utah Geological Association members who make annual UGA publications possible, and the American Association of Petroleum Geologists-Rocky Mountain Section Foundation for a generous grant for desktop publishing of these geosite papers.

Design and desktop publishing by Jenny Erickson, Graphic Designer, dutchiedesign.com, Salt Lake City, Utah.

This is an open-access article in which the Utah Geological Association permits unrestricted use, distribution, and reproduction of text and figures that are not noted as copyrighted, provided the original author and source are credited. See the Utah Geological Association website, www.utahgeology.org, and Creative Commons https://creativecommons.org/licenses/by/4.0/ for details.

Suggested citation for this geosite:

Kowallis, B.J., and Wald, L.C., 2019, Rock Canyon near Provo, Utah County-a geologic field laboratory, in Milligan, M., Biek, R.F., Inkenbrandt, P., and Nielsen, P., editors, Utah Geosites: Utah Geological Association Publication 48, 15 p., https://doi.org/10.31711/geosites.v1i1.58.

\section{Presidents Message}

I have had the pleasure of working with many different geologists from all around the world. As I have traveled around Utah for work and pleasure, many times I have observed vehicles parked alongside the road with many people climbing around an outcrop or walking up a trail in a canyon. Whether these people are from Utah or from another state or country, they all are quick to mention to me how wonderful our geology is here in Utah.

Utah is at the junction of several different geological provinces. We have the Basin and Range to the west and the Central Utah Hingeline and Thrust Belt down the middle. The Uinta Mountains have outcrops of some of the oldest sedimentary rock in Utah. Utah also has its share of young cinder cones and basaltic lava flows, and ancient laccoliths, stratovolcanoes, and plutonic rocks. The general public comes to Utah to experience our wonderful scenic geology throughout our state and national parks. Driving between our national and state parks is a breathtaking experience.

The "Utah Geosites" has been a great undertaking by many people. I wanted to involve as many people as we could in preparing this guidebook. We have had great response from authors that visit or work here in the state. Several authors have more than one site that they consider unique and want to share with the rest of us. I wanted to make the guidebook usable by geologists wanting to see outcrops and to the informed general public. The articles are well written and the editorial work on this guidebook has been top quality.

I would like to personally thank Mark Milligan, Bob Biek, and Paul Inkenbrandt for their editorial work on this guidebook. This guidebook could not have happened without their support. I would like to thank Jenny Erickson for doing the great desktop publishing and the many authors and reviewers that helped prepare the articles. Your work has been outstanding and will certainly showcase the many great places and geology of Utah. Last, but not least, Thank you to the American Association of Petroleum Geologists, Rocky Mountain Section Foundation for their financial support for this publication.

Guidebook 48 will hopefully be a dynamic document with the potential to add additional "geosites" in the future. I hope more authors will volunteer articles on their favorite sites. I would like to fill the map with locations so that a person or family looking at the map or articles will see a great location to read about and visit. Enjoy Guidebook 48 and enjoy the geology of Utah.

Peter J. Nielsen

2019 UGA President 


\section{INTRODUCTION}

Rock Canyon near Provo, Utah is an ideal outdoor laboratory. The canyon has been known and explored for many years by scientists and students for its fascinating geology, biology, and botany. It is also a favorite location for rock climbers, hikers, and other outdoor enthusiasts. Facilities near the mouth of the canyon including parking, restrooms, a lecture amphitheater, and a covered pavilion with picnic tables provide an ideal location for visitors (figure 1).

Geology is the focal point of this beautiful canyon with a history that stretches from the Precambrian (about 700 million years ago) to the Wasatch fault and Lake Bonneville, which covered much of western Utah at its peak roughly 18,000 years ago (figure 2). Excellent exposures of the rocks allow visitors to see features clearly and piece together the history of the canyon. The oldest rocks are glacial deposits of the Mineral Fork Tillite. The tillite is overlain by a thick section of Paleozoic rocks of Cambrian to Permian age, all of which have been deformed into an asymmetric, overturned fold formed during the Sevier orogeny, a roughly 140 to 50 million year old mountain building event. The upper reaches of the canyon were sculpted by glaciers during the Pleistocene and deposits of the Provo and Bonneville levels of Lake Bonneville are found at the mouth of the canyon, now cut by a recent alluvial fan. Also, at the mouth of the canyon are excellent exposures of features associated with the Wasatch fault.

Visitors are asked to please respect the canyon's natural beauty and minimize human impact by adhering to regulations and by hiking on designated paths. Please be careful not to litter; remember, what you take in, you must also take out. The mouth of Rock Canyon, including the pavilion, restrooms, and parking lot is maintained by the city of Provo. The amphitheater is available to the public for special programs or outdoor classroom use. The remainder of the canyon lies within the Uintah National Forest and is under the jurisdiction of the Pleasant Grove Ranger District. If you have any questions about the pavilion and park area please contact the Provo City Parks and Recreation Department. For questions regarding the canyon please contact the National Forest Service.

Although the canyon is beautiful, it also contains some hazards that visitors should be aware of. Among the plants that thrive in the lower reaches of the canyon is poison ivy, a plant that causes a severe, blistering rash in most people. Hikers should learn to recognize this plant before exploring the canyon. The canyon is also home to rattlesnakes. These snakes will generally try to avoid humans, but if disturbed or cornered, they will strike and their bite is painful and dangerous. If bitten, you should seek immediate med-

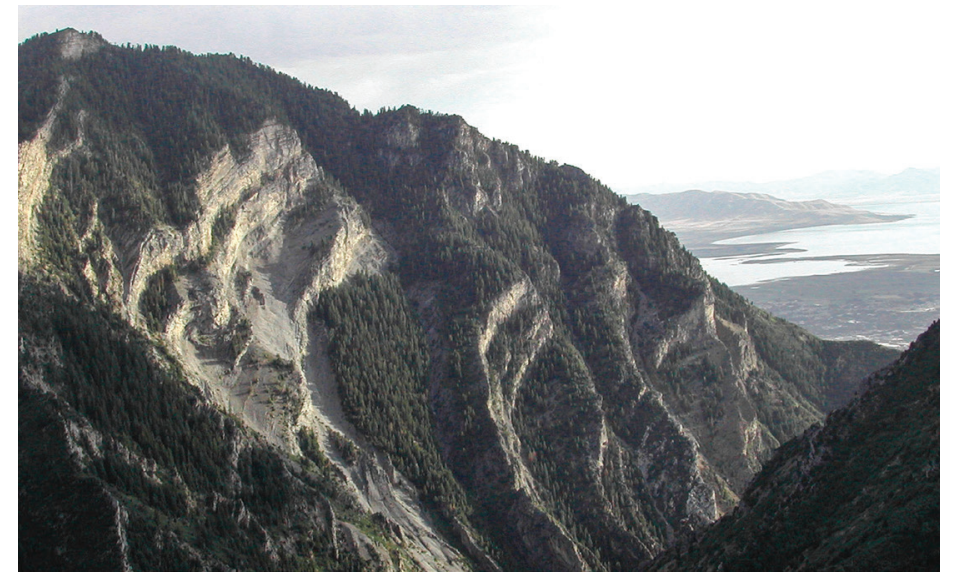

Figure 2. Looking down Rock Canyon to the west toward Utah Lake. The prominent folded rocks shown here are Mississippian Humbug Formation, Deseret Limestone, and Gardison Formation. Photo is courtesy of Beau Walker.

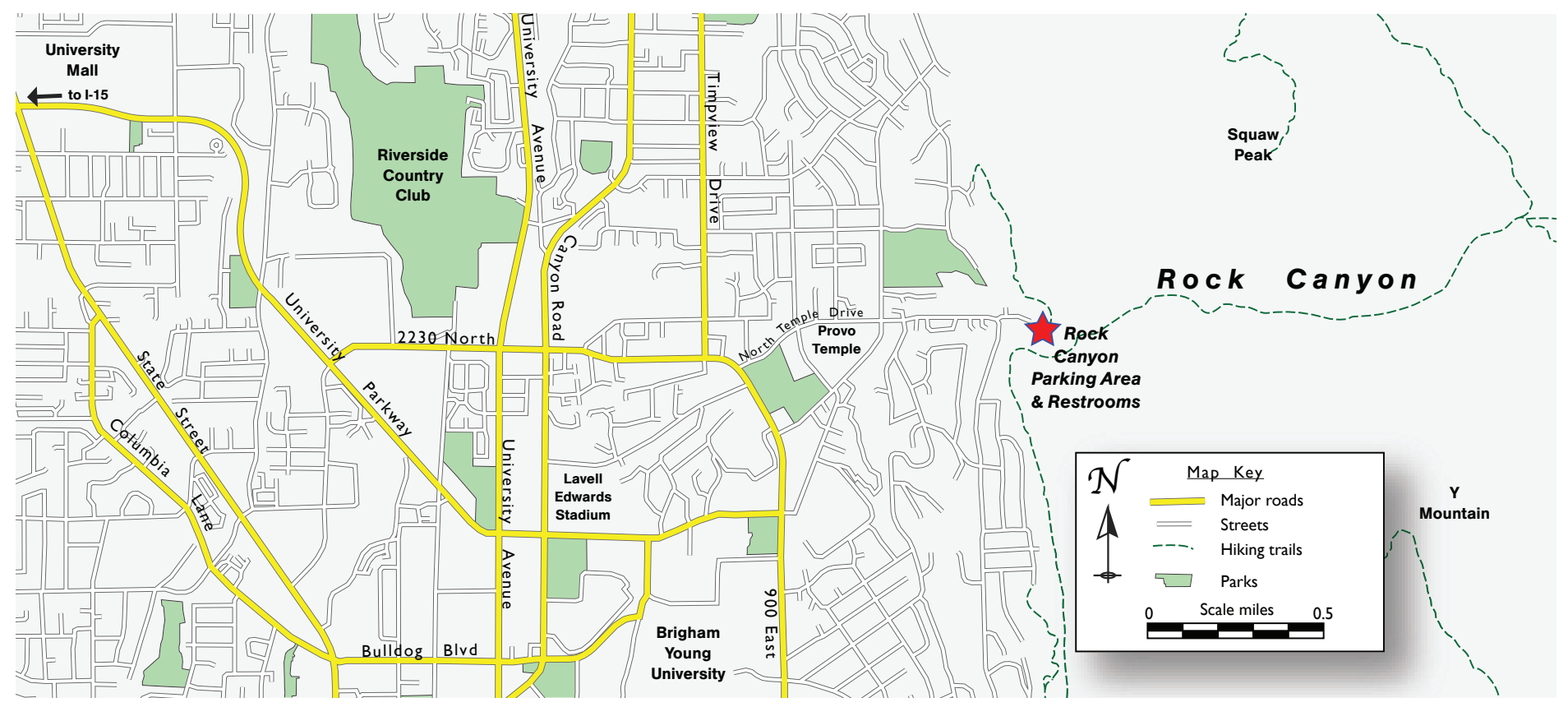

Figure 1. Index map showing the location of Rock Canyon and the major roads providing access to the canyon. The star shows the location of the parking area, rest rooms, and pavilion at the mouth the of the canyon. 
ical attention. Finally, the canyon has many great places for rock climbing, but loose rock and improper gear or training can and has resulted in disaster. One or more serious accidents or deaths occurs each year in the canyon due to falls from rocky slopes or cliffs.

\section{EARLY CANYON EXPLORATION}

J. Marinus Jensen (1924) self-published a book entitled the Early History of Provo, Utah. Jensen reports that the first mention of Rock Canyon in local history is related to the difficult time the early settlers of Fort Utah (later named Provo) had with the Ute Indians. The Utes were understandably disturbed by the pioneers taking over their valley. The disputes peaked in 1850 when a battle broke out along the Provo River between approximately 70 Indians, led by Big Elk, and a militia of Mormon men. For several days the battle continued until one evening the Indians, many of whom were wounded, took flight. In their escape they split into two groups; one headed south toward Spanish Fork, and the other smaller group went toward Rock Canyon. Big Elk headed the Rock Canyon group; however, he was severely wounded and died near the mouth of the canyon. As the militia approached Rock Canyon in pursuit of the Indians, it is rumored that Big Elk's squaw attempted to climb the cliffs, but fell and was killed. Squaw Peak, near the mouth of the canyon, was supposedly named for the incident. Frequent travel into Rock Canyon began after July of 1855 when "William M. Wall was given a grant to build a road. On completion of the road he was to be permitted to charge fifty cents for each load of wood hauled out of the canyon. There was also a provision in the order to the effect that the grantee should allow all persons desiring to do so, to work on the road; and that they should receive, as compensation therefore, the right to haul out eight loads of wood for every day's work performed." No mention was made of any fee for geology excursions, rock collecting, or rock climbing; evidently they were not "popular" activities back then.

Due to the need for water and timber, the early settlers of Utah Valley exploited these resources and depleted them (Bush, 1995). During the 1860's, Rock Canyon was settled by a few pioneer families and Rock Canyon Creek also provided the early settlers in Provo with drinking water (Jensen, 1924). Some land was cleared in the canyon to use for farming including fruit orchards (Bush, 1995). However, the land proved to be too hostile for the European farming methods, and was quickly abandoned. The canyon proved to be more amenable to raising cattle and sheep. Livestock were taken up the canyon to graze during the summer and this quickly became so popular that overgrazing stripped the land of most of its vegetation (Jensen, 1924; Wilson, 1988). This in turn led to flooding where debris and water from the canyon flowed out into the valley often causing damage to farms and structures built in or near the mouth of the canyon. Flood incidents occurred quite frequently between 1896 and 1984 (Bush, 1995). One of the most disastrous floods occurred on 28 July 1936 (figure 3 ).
Starting in about 1925, citizen groups in the valley began to try and address the flooding problems, and with the help of the federal government, some progress was made, including the terracing of the high, steep, rocky slopes of the canyon by the Civilian Conservation Corps (CCC) during 1933 and 1934 (Bush, 1995). But despite these efforts, overgrazing in the canyon continued and it was not until after the flooding in three consecutive years in the 1950's that the overgrazing problem was addressed (Bush, 1995).

\section{Cloudburst Out Of Rock Canyon Inundates Farms}

More Than a Dozen Farms in Path of Flood Damaged By Silt and Mud; Flood Barrier At Mouth of Canyon Swept Away

A torrent of mud rolled out of Rock canyon yesterday afternoon and evening, swept away part of the flood contro dam, and poured black waves of silt and slime over a dozen farms in the Pleasant View region.

Today, as ranchers in the path of the flood waded in knee-deep mud to salvage farm equipment and collect livestock, the damage to crops, land, and buildings was estimated roughly at $\$ 20,000$.
Figure 3. Headline and part of the article from the Provo Daily Herald, 29 July 1936, p 1 , reporting on the flood out of Rock Canyon the previous day. Rain had begun in the mountains in the early afternoon. Lewis Richards, who was at his homestead in the canyon heard the roaring of the flood at about 2 p.m. and reported that, "It looked like the whole mountain had begun to move." Flooding also occurred from similar storms in other central Utah communities the same day.
The most recent serious flooding problems occurred in 1983 after a series of wetter than normal months beginning in September of the previous year. The wet cool weather persisted until late May and early June of 1983 when the temperatures warmed and flooding began. A Provo Daily Herald headline on the front page of the May 30th edition that year read "Crews Sandbag Temple View," as the road out of Rock Canyon was temporarily turned into a river (figure 4). After the 1983 floods, the catchment basin at the mouth of the canyon was enlarged to guard against further problems. This basin now serves as a city park when not needed for flood control.

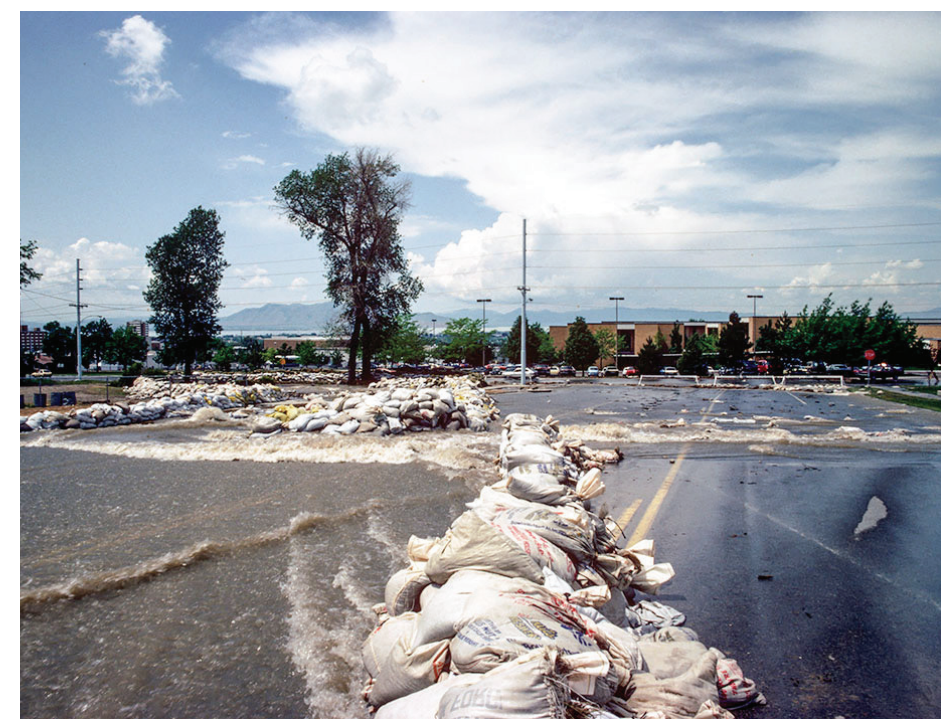

Figure 4. Flood waters flowing out of Rock Canyon along Temple View Drive in Provo in early June 1983. Photo by Bart Kowallis. 
ROCK CANYON, PROVO UTAH FORMATIONS THICKNESS - $\mathrm{ft}$.

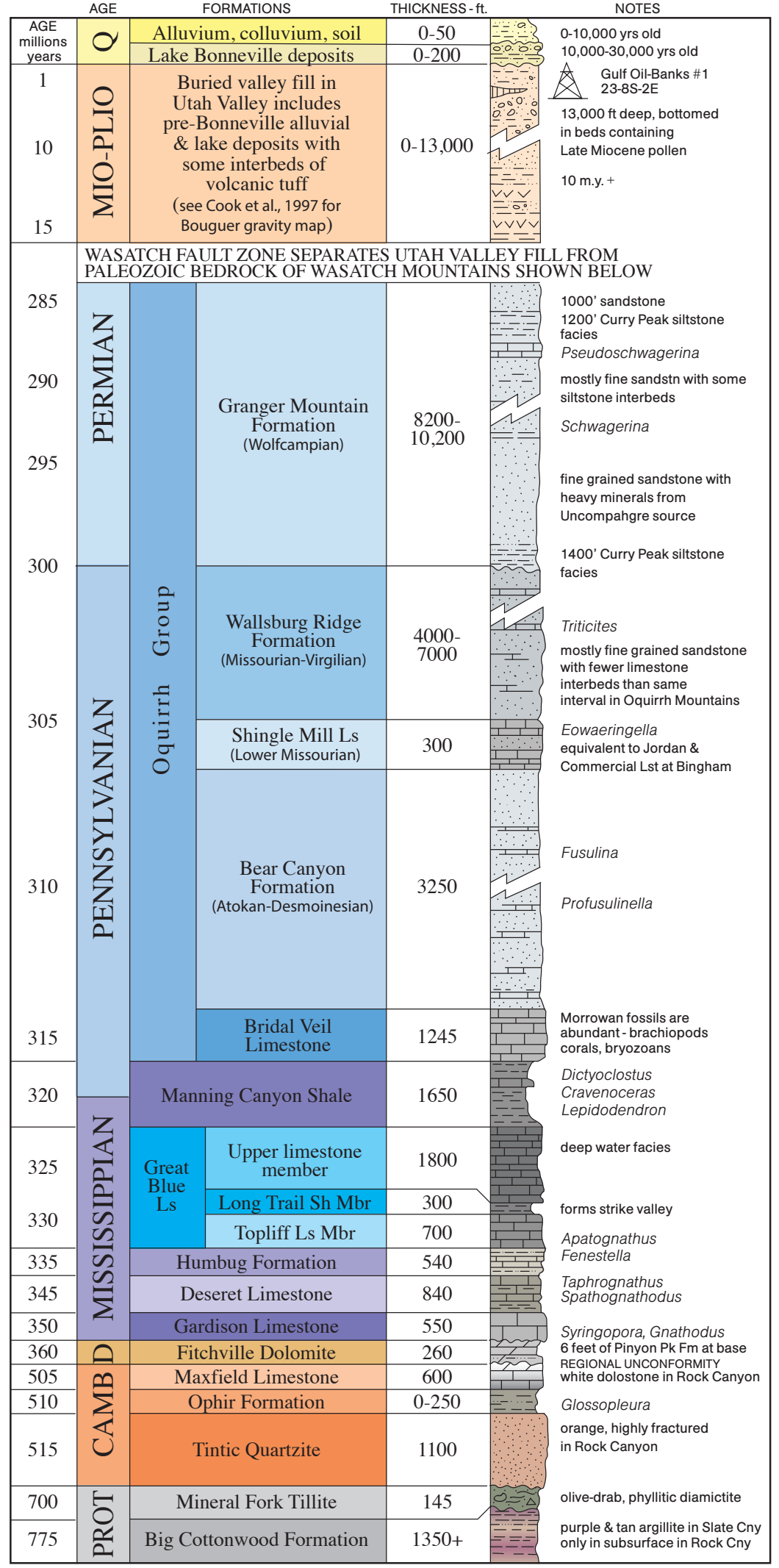

Figure 5. Stratigraphic column for the Rock Canyon area modified from Hintze and Kowallis (2009). The Big Cottonwood Formation shown on the column is not exposed in the canyon, but it is just a couple miles south in Slate Canyon. Also, the Mio-Pliocene sediments are only in the subsurface of the valley deposits. This thick pile of sediments in the valley are evidence of the amount of uplift and erosion that has occurred along the Wasatch fault zone over the last 10-12 million years. In the column of notes are listed a few of the fossils (in italics) that occur in these rocks. 


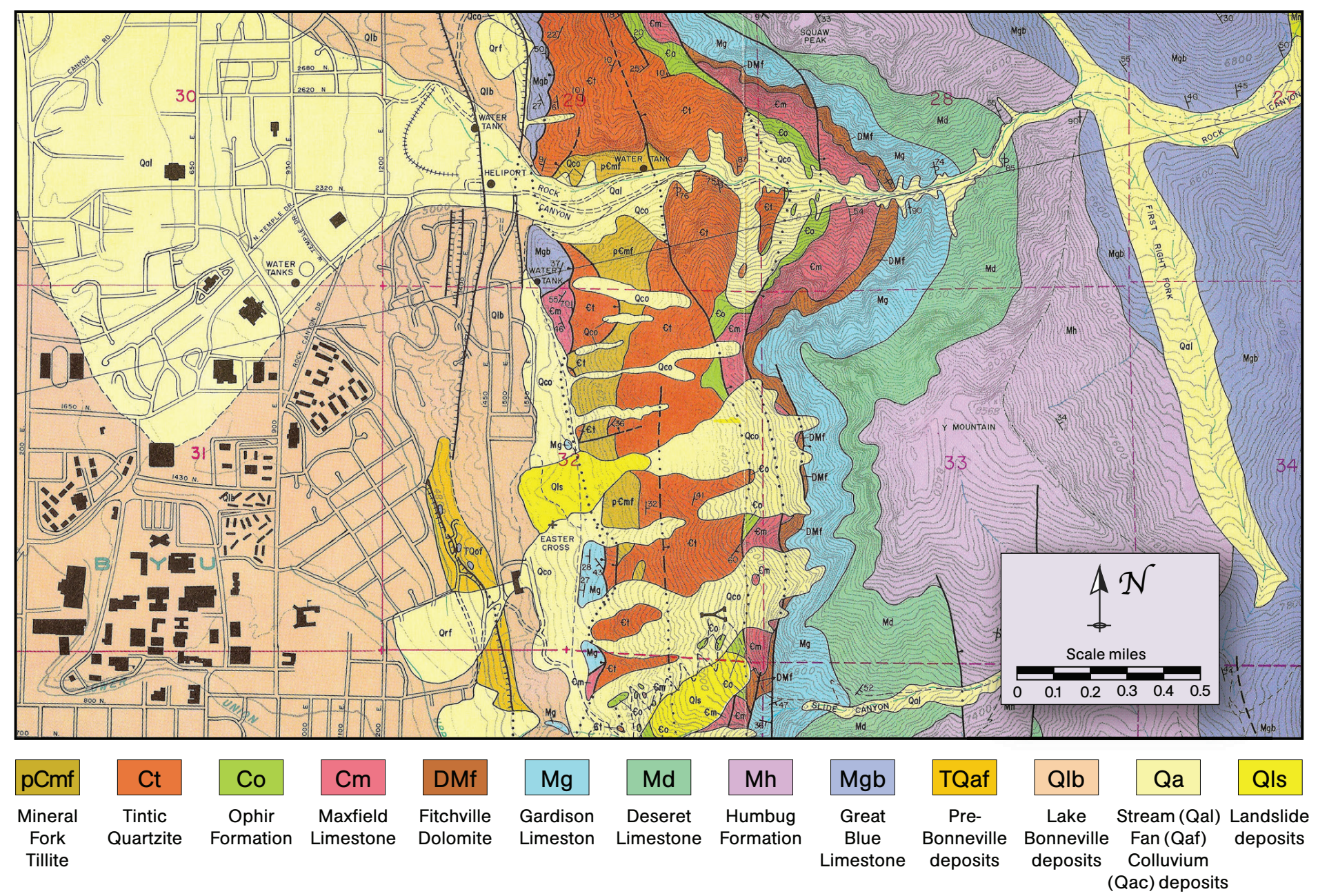

Figure 6. Geologic map of the Rock Canyon area showing the location of the BYU campus in relation to Rock Canyon reproduced from Hintze (1978). The current parking lot, rest room, and pavilion are located approximately where the words "Rock Canyon" are on the map.

\section{GEOLOGIC HISTORY OF ROCK CANYON}

The rocks exposed in Rock Canyon range in age from Neoproterozoic to Recent (figures 5 and 6; Baker, 1972; Hintze, 1978; Davis, 1983). The oldest rocks are exposed near the mouth of the canyon while the youngest bedrock units are found on the high peaks (Cascade Mountain, Y Mountain, and Provo Peak) at the head of the canyon.

\section{Neoproterozoic Rocks (Precambrian)}

The oldest rocks found in Rock Canyon are diamictites of the Mineral Fork Tillite that are well exposed on the north canyon wall near the water storage tank (figure 6). The outcrops are composed of cobbles and pebbles of quartzite, dolomite, and limestone (with rare clasts of other rock types) surrounded by a fine-grained matrix (Baker 1973), which has been weakly metamorphosed producing a secondary foliation and phyllitic character in the matrix (figure 7). Over the years, there has been some debate as to the origin of these deposits, but the general consensus currently is that they were deposited by ancient glaciers (Varney, 1976; Ojakangas and Matsch, 1980; Christie-Blick, 1983; Crittenden and others, 1983; Link and others, 1994; Christie-Blick, 1997).
Ojakangas and Matsch (1980) and Matsch and Ojakangas (1991) proposed that the lower part of the formation was deposited in a terrestrial glacial environment, while the upper part was deposited in a marginal-marine glacial environment (figure 8), and that the entire sequence was deposited by glaciers in a more temperate environment rather than a polar environment. Christie-Blick (1982) questioned the idea of a terrestrial glacial environment, instead preferring a submarine, grounded-ice environment.

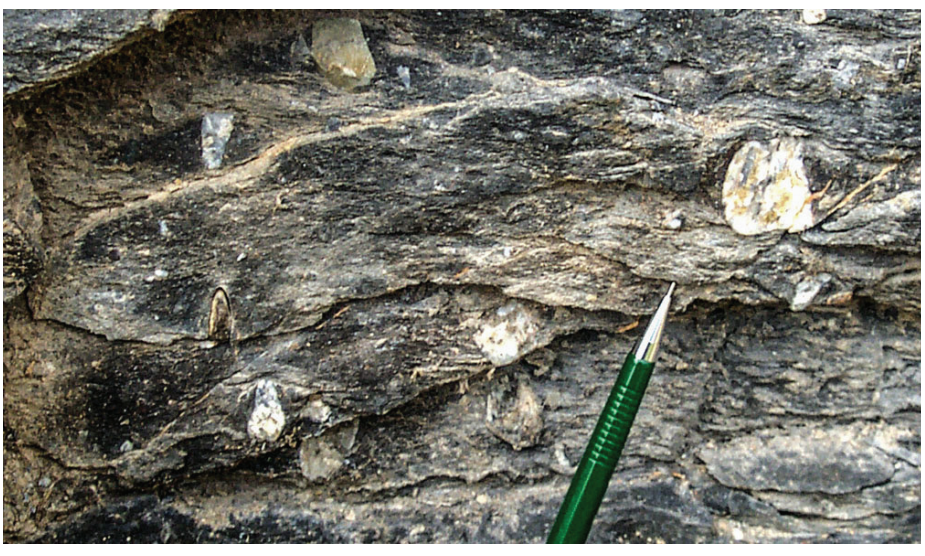

Figure 7. Close-up view of Mineral Fork Tillite showing small pebbles of quartzite and dolomite floating in a fine-grained matrix that has been metamorphosed producing foliation that in places becomes a crenulation cleavage. 

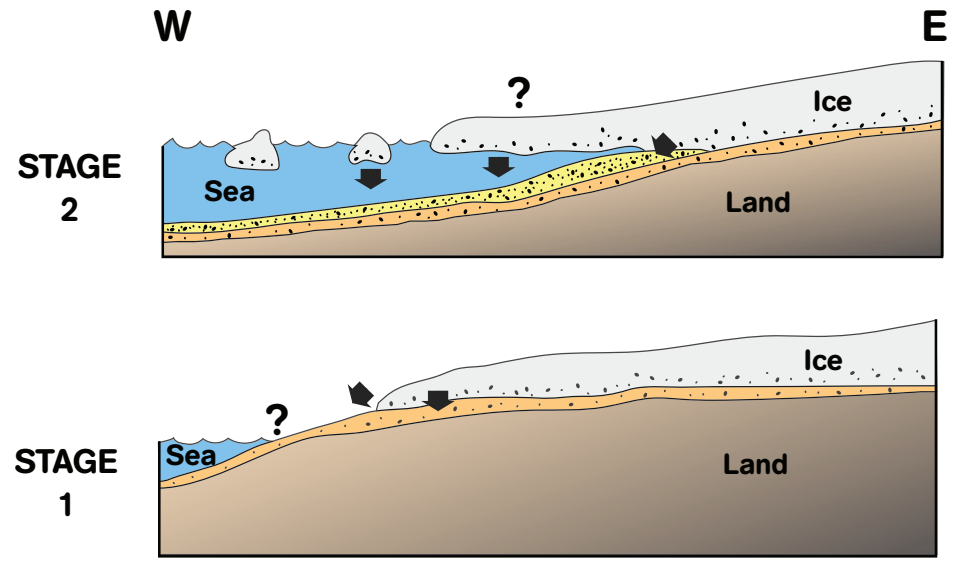

Figure 8. Two-stage model for deposition of the Mineral Fork Tillite proposed by Matsch and Ojakangas (1991). Stage 1 was a deposition in a terrestrial glacial setting while stage 2 was a marginal marine glacial setting. Arrows indicate input of sediment into the deposits.

\section{Cambrian to Devonian Rocks}

The Cambrian was a time of shallow seas and shorelines in what is now Utah. The oldest Cambrian rock unit in the canyon is the Tintic Quartzite. It is an orange- to tan-weathering quartzite that is light greenish gray on unweathered surfaces. The sandstone from which the quartzite originated was composed of fairly clean, rounded to subrounded quartz grains of fine- to medium-grain size with local coarse-grained interbeds (Baker and others, 1949; Lochman-Balk, 1976). Cross-bed sets up to 3 to 4 feet $(1 \mathrm{~m})$ thick can be observed in this rock unit. Some layers contain abundant well-rounded pebbles of quartzite or vein quartz (figure 9) and at several localities, trace fossil burrows (called Skolithos) occur in the outcrops (figure 10; see also Peterson and Clark, 1974).

The Tintic Quartzite unit outcrops as highly-fractured, rough ledges and cliffs in the lower part of the canyon (figure 11). At the mouth of the canyon, the Tintic Quartzite is gently dipping, but a short distance into the canyon the unit is vertical to slightly overturned. It is in some of these vertical quartzite beds where rock climbing has become quite popular.

Toward the top of the Tintic Quartzite the unit interfingers with the overlying Ophir Shale (Baker, 1972, 1973). Like the Tintic Quartzite, the Ophir Shale has been slightly metamorphosed and would be more properly classified as a phyllite rather than a shale. Poorly preserved fragments and pieces of trilobites may be found in the Ophir Shale.

The final Cambrian unit exposed in Rock Canyon is the Maxfield Limestone (figures 5 and 6). The lower two-thirds of this formation consists of a mottled dark- to medium-gray limestone, while the upper third is a medium- to very light-gray banded dolomite (Granger and other, 1952; Hintze, 1978) Fossils are sparse in the Maxfield Limestone, but some trilobite, gastropod, and bryozoan fragments have been found, as well as conodont microfossils (Hintze, 1978; Clark and others, 2014).

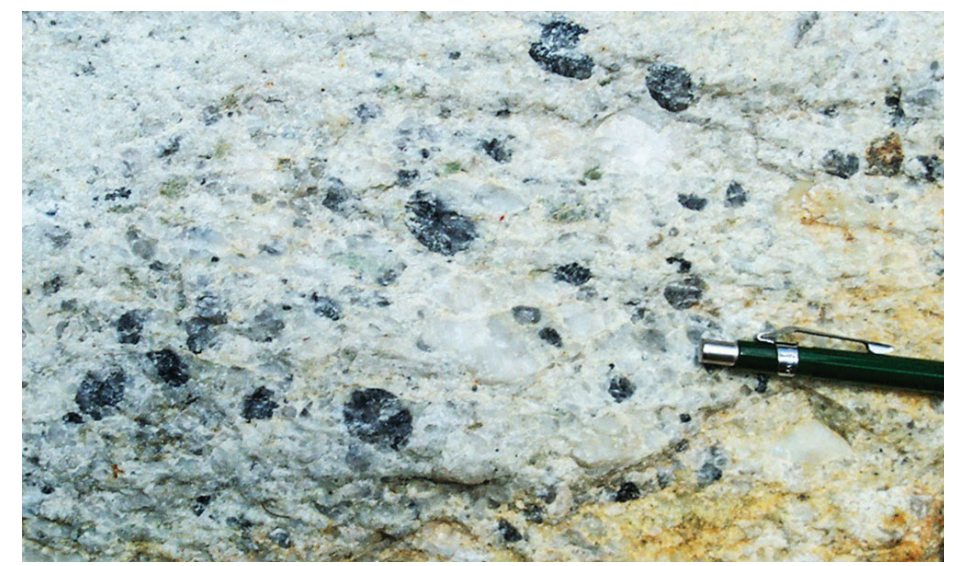

Figure 9. Small pebbles of dark quartzite and white vein quartz withing the Tintic Quartzite. Weathered (orange-tan, lower right) and unweathered (light gray) surfaces of this unit are shown.

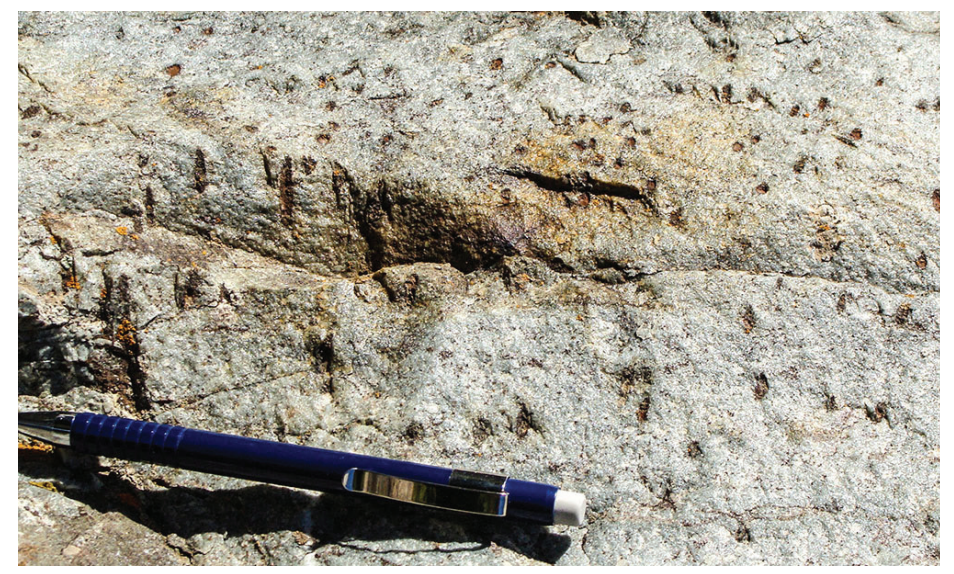

Figure 10. Rusty-colored Skolithos burrow in the Tintic Quartzite.

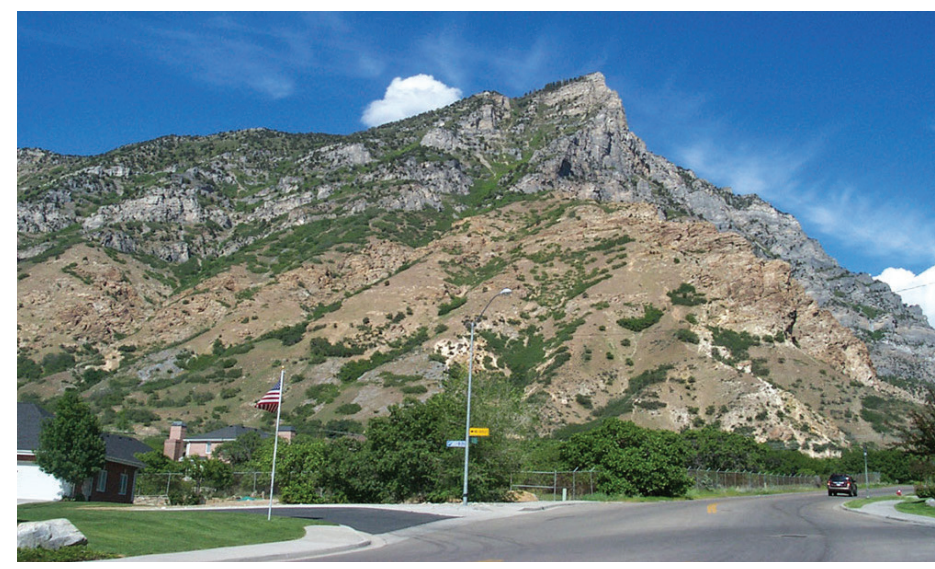

Figure 11. Squaw Peak as seen from North Temple Drive. The orangish tan, gently dipping Tintic Quartzite is distinctive at the base of the peak and overlain by gray Paleozoic dolomite and limestone beds.

The Cambrian depositional system is represented in figure 12 with shoreline sands eastward of a broad subtidal carbonate platform and deeper water slope deposits to the west (Hintze and Kowallis, 2009). In the Rock Canyon area, the Tintic Quartzite was deposited as shoreline and near shore sands. Then as sea level rose, the shoreline moved farther east. First the lagoonal muds of the Ophir Shale and then the carbonates of the Maxfield Limestone were deposited atop the sand due to a major pulse of sea level rise. 


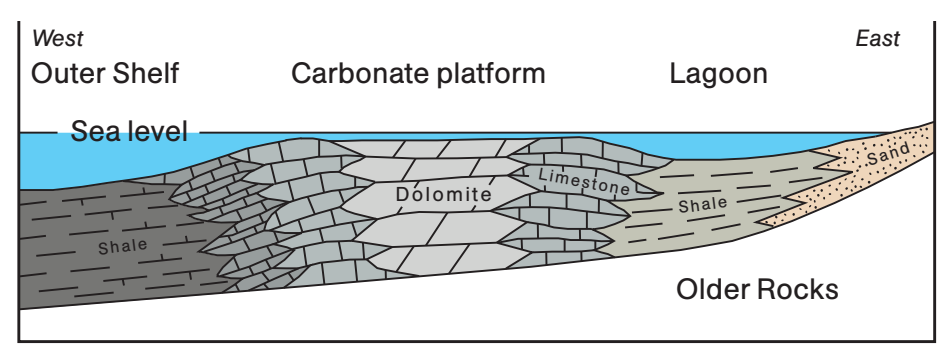

Figure 12. Cambrian depositional system (modified from Hintze and Kowallis, 2009).

Following Cambrian time, a major period of erosion and non-deposition occurred in the Rock Canyon area due to a drop in sea level. This unconformity disappears to the west where deposition was still occurring. Beginning about 20 to 25 miles (30-40 $\mathrm{km}$ ) west of Rock Canyon, Cambrian-age strata become thicker. In addition, Ordovician rocks, which are absent in Rock Canyon, appear and also thicken to the west. The area between these thicker deposits off to the west and the thinner deposits to the east is called the "hinge line" or "Wasatch line" and marks the transition from the stable shallow continental shelf margin to a more rapidly subsiding part of the continental margin called a miogeosyncline (Kay, 1951; Bissell, 1974, Stokes, 1976).

Although rocks of Ordovician and Silurian age are not currently found in Rock Canyon, thin deposits of rocks of these ages likely once existed in this area, but during the early part of the Devonian Period they were eroded away. Later in the Devonian, the ocean again covered the area and sediments were deposited atop the erosional surface. These Devonian-age sediments are relatively thin, accumulating only to a thickness of about 250 feet $(75 \mathrm{~m})$ in the Rock Canyon area (figures 5 and 6 ) and are called the Fitchville Dolomite or Fitchville Formation (Baker, 1972; Hintze, 1978; Hintze and Kowallis, 2009). The Fitchville Dolomite consists of about 20 feet $(6 \mathrm{~m})$ of dolomitic sandstone at the base overlain by relatively unfossiliferous light- to medium-gray, vuggy dolomite (Hintze, 1978). Clark and others (2014) found that the lowermost few feet of the Fitchville Formation in Rock Canyon contain fossil conodonts (microscopic fossils) that correlate this part of the formation to an older Devonian formation called the Pinyon Peak Formation (figure 13), which outcrops in thicker beds to the west of Rock Canyon.

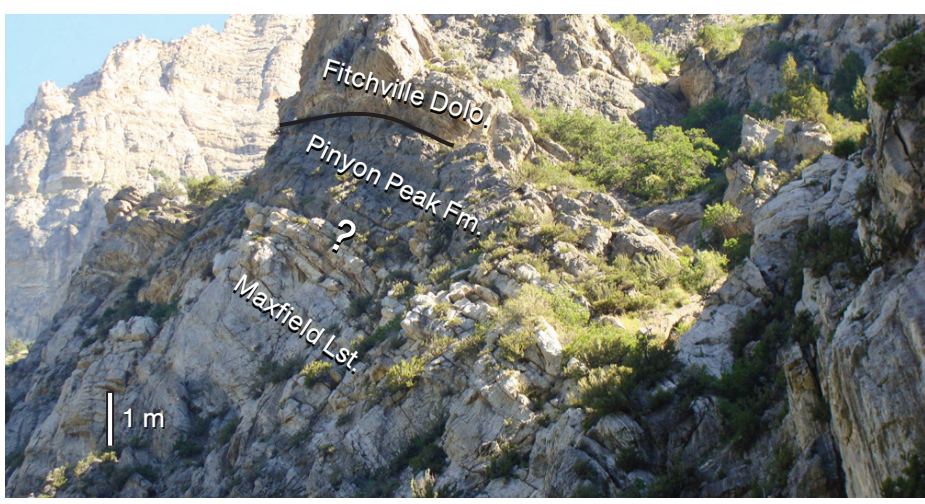

Figure 13. Contact between the Cambrian Maxfield Limestone and Devonian Fitchville Dolomite in Rock Canyon with a few feet of Pinyon Peak Formation between them (modified from Clark and others, 2014).

\section{Mississippian, Pennsylvanian, and Permian Rocks}

The Rock Canyon area remained at or near sea level for the next 100 million years, throughout the Mississippian, Pennsylvanian, and Permian Periods. However, in the Mississippian, an area of increased subsidence developed on the continental shelf margin in the area of northwestern and north-central Utah, which persisted through the Permian. This basin, where thousands of feet of sediment accumulated, is called the Oquirrh Basin (Jordan and Douglass, 1980: Erskine, 1997) and was part of a series of basins and uplifts that formed the Ancestral Rocky Mountains (figure 14; Lee, 1918; Ver Wiebe, 1930; Kluth, 1986; Ye and others, 1996). In the Rock Canyon area, deposits into the Oquirrh Basin during this time period totaled over 20,000 feet $(6000 \mathrm{~m})$ or approximately four miles $(6.5 \mathrm{~km})$ of strata (Baker, 1972; Hintze, 1978). These rocks (including the Gardison Limestone, Deseret Limestone, Humbug Formation, Great Blue Limestone, Manning Canyon Shale, and Oquirrh Group) make up the bulk of the bedrock located from about one mile $(1.6 \mathrm{~km})$ into the canyon to the tops of the highest peaks surrounding the canyon (figure 15). Limestones and sandstones of the Humbug Formation form the capping rocks atop Squaw Peak, while the Manning Canyon Shale forms the valley and slopes below cliffs of the Oquirrh Group through which the Squaw Peak/Rock Canyon picnic area road winds. As you hike through the canyon, you may find some marine fossils (corals, snails, bivalves, etc.) within these rock formations as well as darker and harder lumps of chert. Limestones will fizz with the applica-

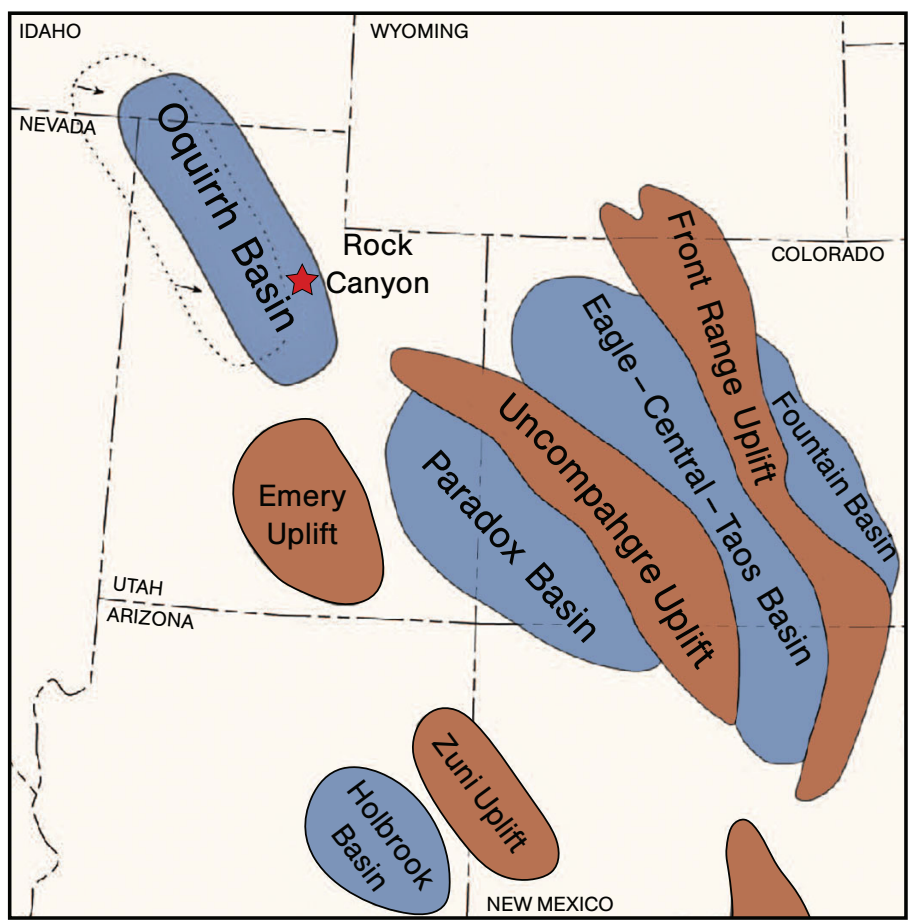

Figure 14. Middle Paleozoic basins and uplifts showing the approximate location of Rock Canyon in the Oquirrh Basin (modified from Hintze and Kowallis, 2009). This period of uplift and basin subsidence formed mountains that are called the Ancestral Rocky Mountains. The dashed line shows the location of the Oquirrh Basin at the time it formed and deposits accumulated. Later these rocks were thrust to the east during the Cretaceous Sevier orogeny. 


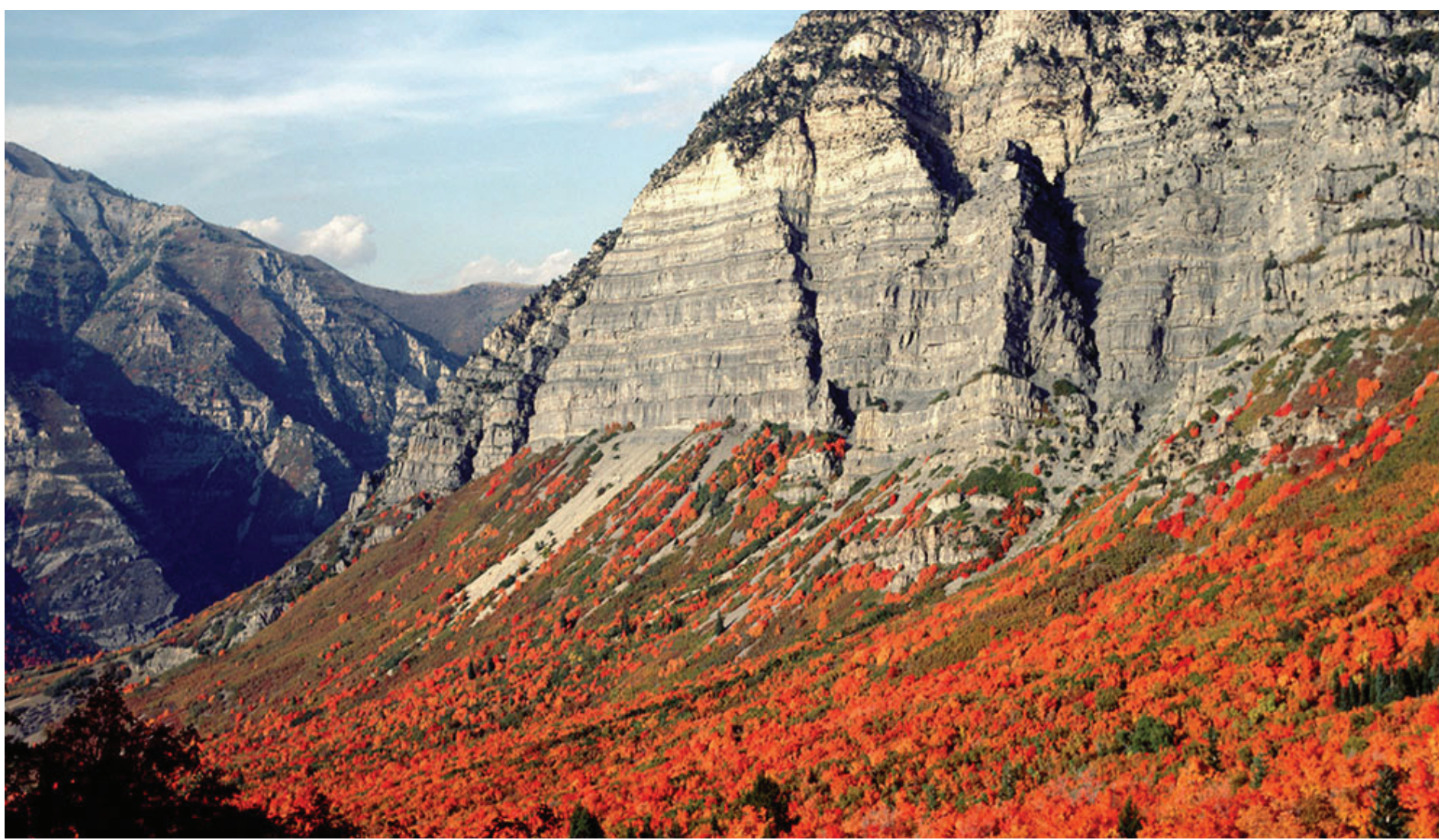

Figure 15. Fall colors grace the maples growing in the slope-forming Manning Canyon Shale (Mississippian) at the base of a cliff on Cascade Mountain. The cliffs of Cascade Mountain are formed from the light-and medium-gray beds of the Bridal Veil Limestone with tree covered crags above the cliffs of the light-tan sandstones of the Bear Canyon Formation, both part of the Oquirrh Group (Pennsylvanian).

tion of weak hydrochloric acid, while dolostones will only fizz if you first scratch the surface or powder some of the rock. Chert will not fizz and is much harder than limestone or dolostone.

\section{Mesozoic Mountain Building - The Sevier Orogeny}

Following the end of the Paleozoic Era, Utah ceased to be the western margin of the North American continent. During a long span of approximately 150 million years, fragments of continental and oceanic plates collided with western North America adding much of what is now Nevada, California, Oregon, and Washington. The collision of these fragments caused uplift and deformation in the rocks that had previously been deposited during the Precambrian and Paleozoic. This mountain building event, called the Sevier orogeny, created a high range of mountains in central Utah that we call the Sevier fold and thrust belt (Armstrong, 1968; DeCelles and Coogan, 2006).

Erosion of these mountains left thick deposits of sandstone, conglomerate, and shale off to the east (Young, 1966). None of this erosional debris is visible in Rock Canyon, but the deposits created by the erosion of the Sevier mountains can be seen in Spanish Fork Canyon a few miles to the south. What is visible in Rock Canyon are the folds, faults, and fractures created when the Precambrian and Paleozoic rocks, which had been deposited several tens of miles to the west of Rock Canyon, were folded and thrust up over younger rocks (figures 16, 17 and 18). The thrust fault and younger rocks underneath the thrust are not exposed in Rock Canyon but they are exposed to the south near the town of Nephi, Utah and to the east in Spanish Fork Canyon.

As the strata were folded and fractured, some of the rock units were deformed more plastically than others. The Ophir Shale, for example, is not highly fractured and has been substantially thickened in some parts of the fold and thinned or completely squeezed out of other parts (figure 18). This is similar to what happens when you squeeze or fold a tube of toothpaste-the paste gets thinned and thickened in different parts of the tube. On the other hand, units like the Tintic Quartzite behaved in a brittle manner, fracturing into pieces rather than flowing. Figure 18 shows the major fractures and faults in rock units of Rock Canyon. Dense fracturing and faulting occur in the Tintic Quartzite compared to the other stratigraphic units partly because it was in the core of the fold where deformation was most intense and partly because the quartzite is simply more brittle than the other rock units (figures 18 and 19).

Mountain building ended about 40 million years ago and over the next 20 million years the Sevier fold and thrust belt collapsed and eroded, but left behind the structures formed during mountain building as well as sediments shed to the east off of the mountains as they eroded away. 
(a) Pre-deformation

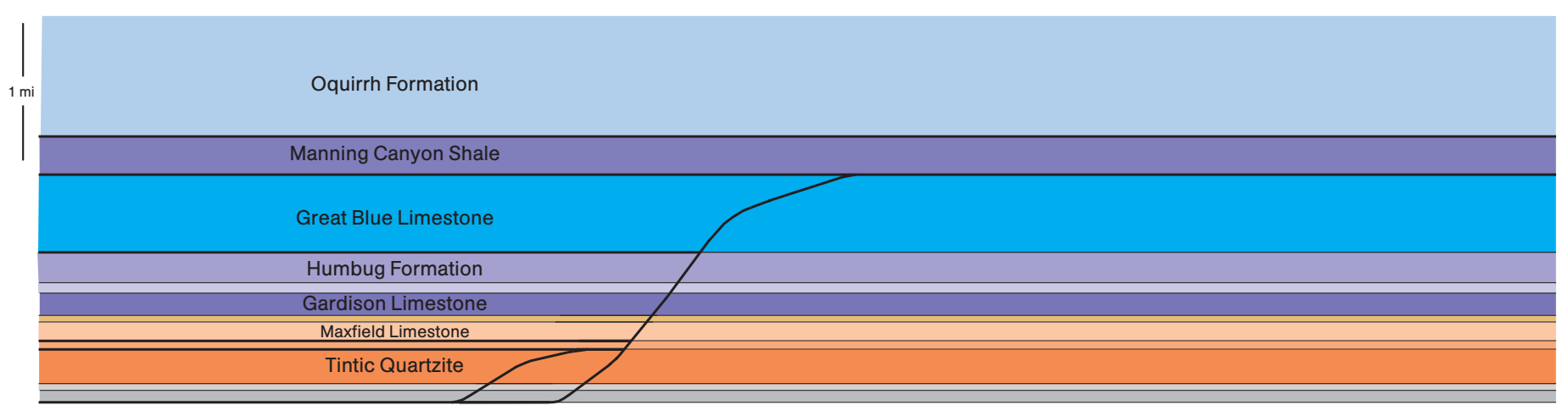

(b) During thrusting

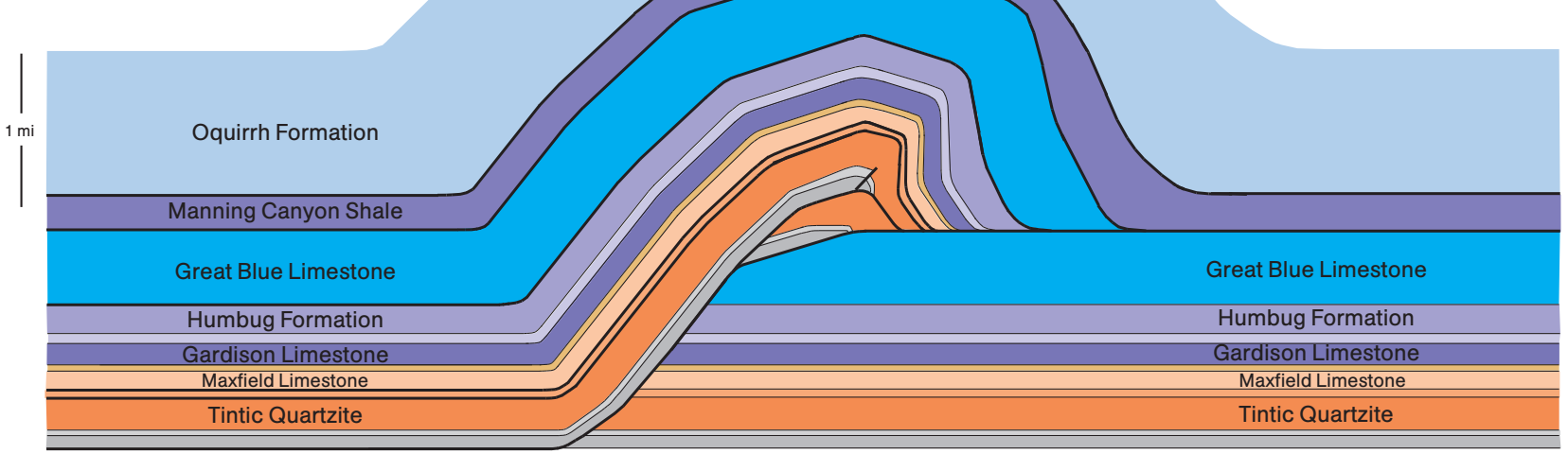

$3 \mathrm{mi}$

(c) Post Wasatch Fault development

$2 \mathrm{mi}$

\section{Utah Valley}

$1 \mathrm{mi}$

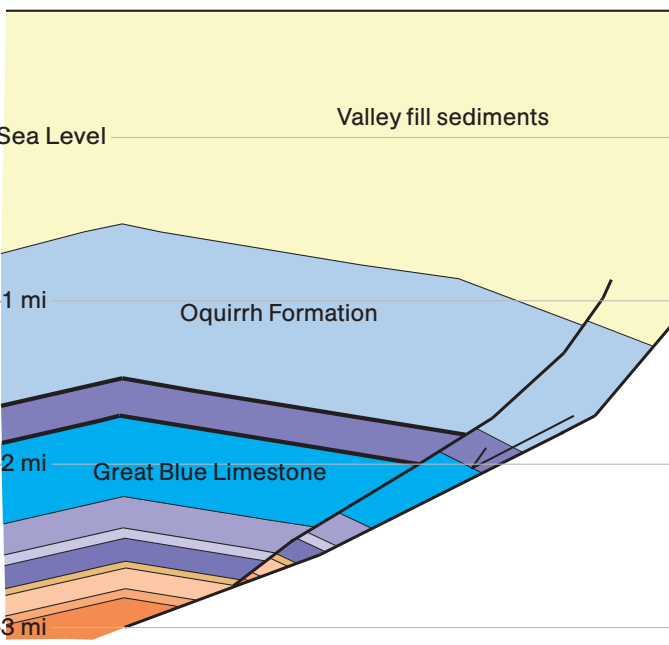

Figure 16. Three stages in the development of the current geology of Rock Canyon. A) Sedimentary rock units prior to the Sevier orogenic deformation. B) Deformation of the rocks due to the Sevier orogeny causing rock layers to be thrust eastward several 10's of kilometers and to be folded and faulted. C) Formation of the Wasatch fault and infilling of Utah Valley with material eroded from the uplifted side of the fault. The approximate position of Squaw Peak is shown by the dashed red line. Modified from Wald (2007). 


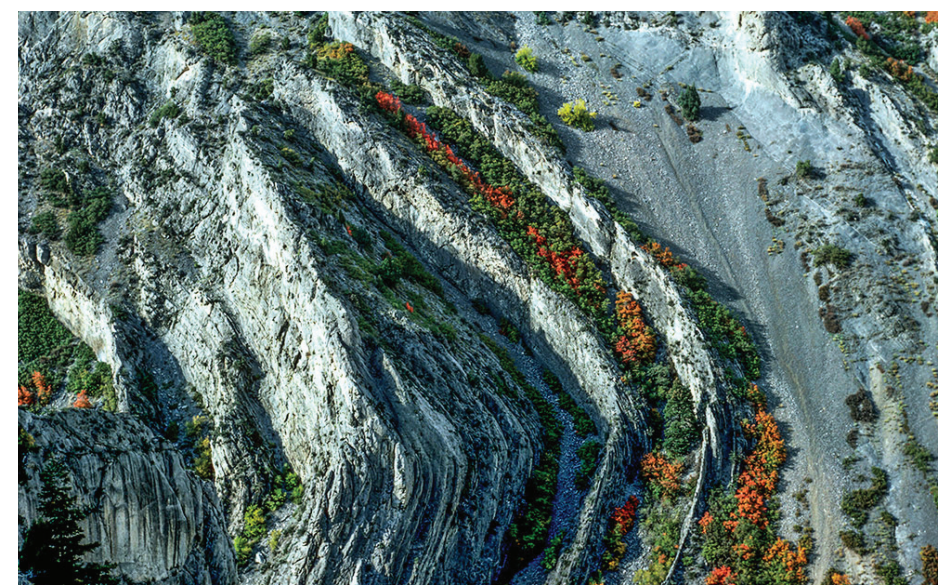

Figure 17. Folded Mississippian strata of the Gardison, Deseret and Humbug formation in Rock Canyon.

\section{The Wasatch Mountains and Wasatch Fault}

Beginning about 20 million years ago western North America began to uplift, extend and pull apart due to warm rocks in the Earth's mantle rising buoyantly beneath the area. This extension and uplift of the west continues up to the present day and is responsible for the formation of the Basin and Range Province (Hintze and Kowallis, 2009). In the Rock Canyon area, this extension is responsible for the formation of the Wasatch Mountains and Utah Valley. A major fault zone, called the Wasatch fault, separates the uplifted mountain block from the down-dropped valley. Over the last 10 to 11 million years the mountains have been going up at a rate of about 0.6 to $1.0 \mathrm{~mm} / \mathrm{yr}$ relative to the valley (Naeser and others, 1983; Parry and Bruhn, 1987; Kowallis and others, 1990).

The uplift along the Wasatch fault causes stress to build up within the Earth and when the rocks cannot store up any more stress, it is released in the form of earthquakes. The fault is composed of about 10 segments that break somewhat independently of each other (figure 20; Machette and others, 1991). Trenches dug across the segments of the Wasatch fault, including one at the mouth of Rock Canyon, have shown that earthquakes of moment magnitude 7.1 to 7.5 occur on each fault segment approximately every 2000 to 4000 years (Machette and others, 1991). With ten fault segments, we can expect that a large surface-rupturing earthquake will occur every 200-400 years somewhere along the Wasatch fault.

Figure 18. Geologic units mapped onto the profile of Squaw Peak on the north wall of Rock Canyon. During the Sevier Orogeny, these rocks were thrust eastward several tens of miles and emplaced in the Rock Canyon area. The main faults and fractures formed during this mountain building event are shown in this sketch of the north wall of the canyon. The red box shows the area blown up in figure 19. Modified from Wald (2007).

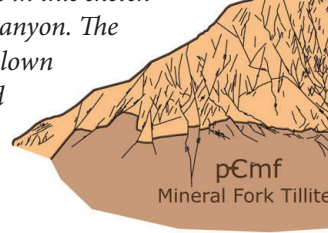

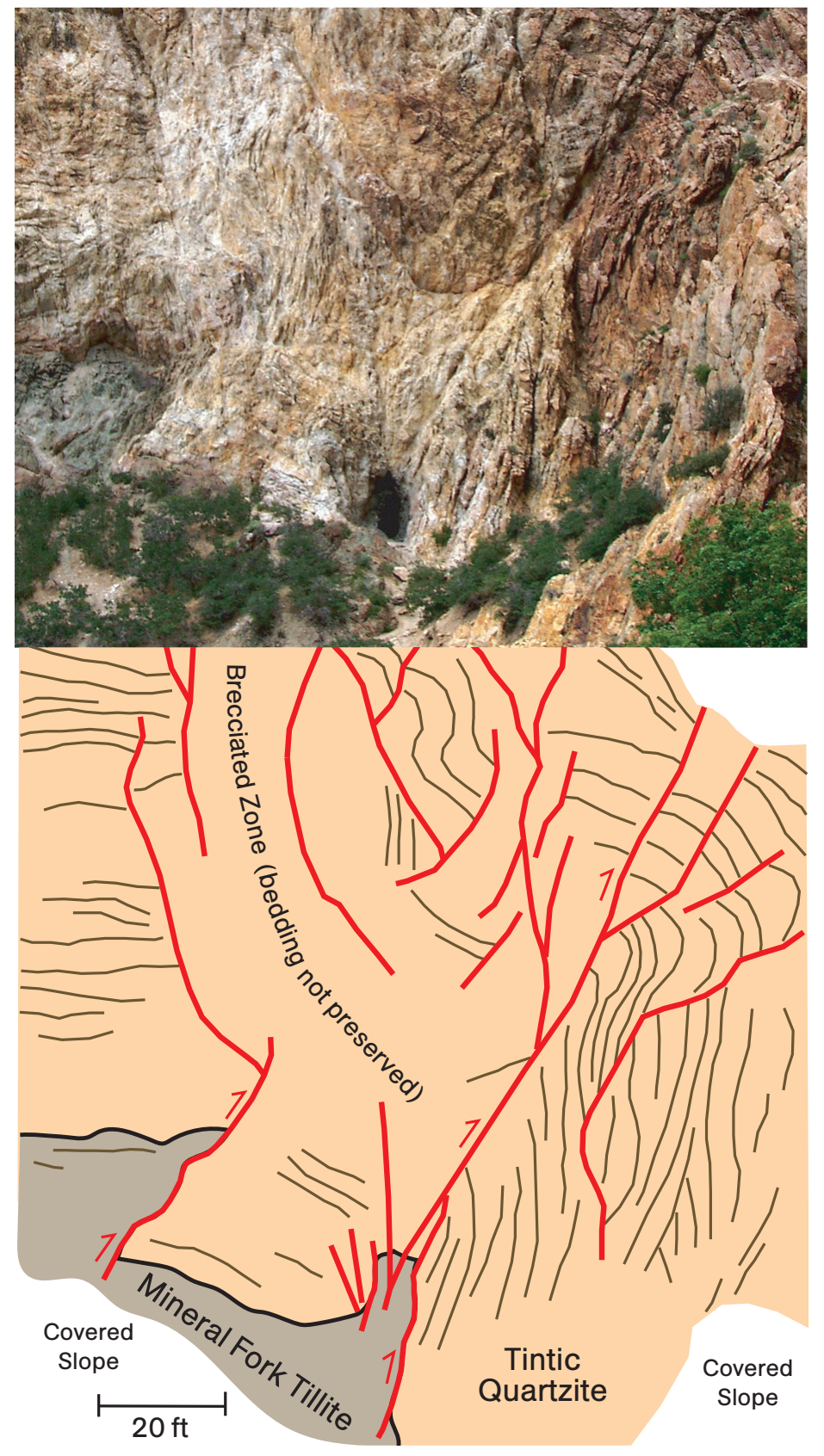

Figure 19. Core zone of Rock Canyon fold. Top - photo of the core zone. Bottom - Interpretive drawing showing the contact between the Mineral Fork Tillite and Tintic Quartzite with faults (red) and bedding (gray). Bedding has been completely destroyed in the central brecciated zone. Modified from Wald (2007). 


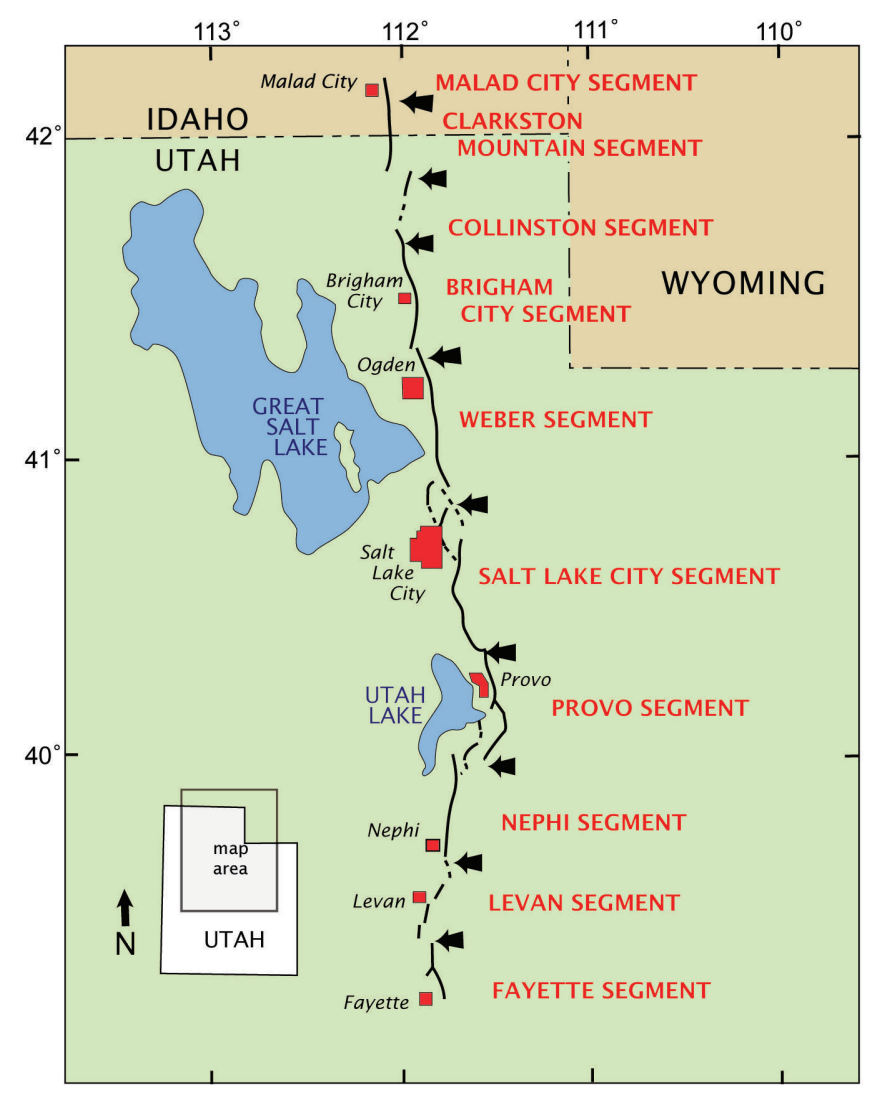

Figure 20. Wasatch fault segments as described by Machette and others (1991). Each segment is capable of producing magnitude 7.0 to 7.5 earthquakes. On average earthquakes occur at intervals of between 500-2500 years on each segment. This figure is modified from Hintze (2005). Rock Canyon is located approximately where the word Provo is on the figure.

From studies of the trench across the fault at Rock Canyon (located near the heliport on figure 6), the most recent large earthquake appears to have occurred approximately 600 years ago (Lund and Black, 1998; Lund, 2005). This earthquake created a fault scarp (a surface fault rupture) 6 to 10 feet $(2-3 \mathrm{~m})$ high, the remnants of which can still be seen along the road up to Rock Canyon (figure 21). Also, if you examine the outcrops of the Tintic Quartzite on the north side of the canyon (ENE of the heliport at the mouth of the canyon on figure 6), you will find that the outcrop of quartzite has been broken and fractured into many small pieces by the movement along the Wasatch fault.

\section{Lake Bonneville and the Pleistocene Ice Age}

About 1.8 million years ago the world-wide climate cooled significantly creating large continental glaciers in North America and Europe. Scientists studying this ice age have identified several periods of ice advances and retreats as the climate alternately cooled and warmed (Petersen and others, 1973). In Utah during periods of cooler climate, mountain glaciers formed in the Wasatch and Uinta mountains and large, fresh-water glacial lakes, called pluvial lakes, formed in the basins to the west (Atwood, 1909; Blackwelder, 1931; Madsen and Currey, 1979). The most recent, and one of the largest of these pluvial lakes was Lake Bonneville (Gilbert,

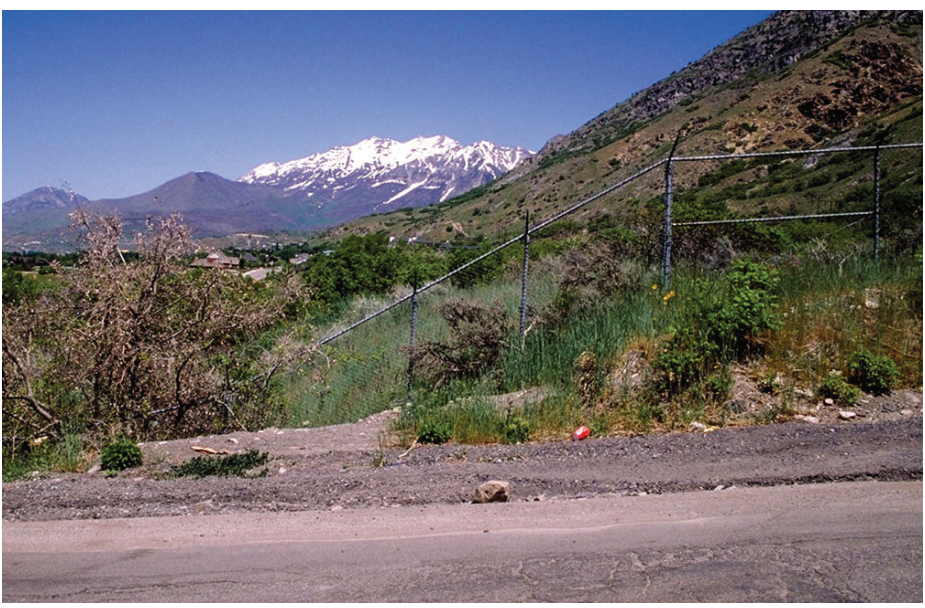

Figure 21. Looking north toward Mount Timpanogos along the Wasatch fault from the road atop the alluvial fan at the mouth of Rock Canyon. Notice the abrupt change in the slope of the chain link fence along the road. This change in the fence line occurs where it crosses the fault scarp created during the most recent large earthquake (which has been dated at about 600 years ago) on the Provo segment of the Wasatch fault. There is no break in the road here because fill was brought in to smooth out the slope. Because the fill is not as firmly compacted as the rest of the alluvial fan sediments, the asphalt typically has cracks running across the road at this location.

1890; Oviatt, 1997). Reheis and others (2014) suggested that about 30,000 years ago the basin now occupied by the Great Salt Lake began to fill and Lake Bonneville was born. The lake grew until it covered almost one quarter of the state of Utah (Hintze and Kowallis, 2009). The lake reached its peak at about 18,000 years ago forming the highest prominent lake terrace. This terrace, called the Bonneville terrace or shoreline, can be seen from the mouth of Rock Canyon (figure 22). Once the lake reached this level, a natural dam near the Utah-Idaho border was breached allowing water to flood and drain out to the north catastrophically onto the Snake River Plain (Reheis and others, 2014; Oviatt and Jewell, 2016) causing the lake level to drop rapidly to a lower level, called the Provo level, where it stabilized for several hundred years. Continuing climate change caused regression of the lake to the present level of the Great Salt Lake. The Provo-level terrace is the flat surface on which most of the Brigham Young University campus is built (figure 6).

In addition to these lake terraces near the mouth of Rock Canyon, visitors can also observe the change in the character of the canyon as they hike to the east. The lower reaches of the canyon have a typical "V" shape produced by stream erosion, but farther into the canyon, just beyond the picnic and camping area on figure 6 , it opens up into a wider " $U$ " shape carved by glaciation (figure 23).

\section{Recent Alluvial Deposits}

After the disappearance of Lake Bonneville, sediments carried by the stream flowing out of Rock Canyon were dumped at the mouth of the canyon forming an alluvial fan (see the fan-shaped deposit on figure 6 outward from the mouth of the canyon). Today, many homes as well as the Provo Temple and Missionary Training Cen- 


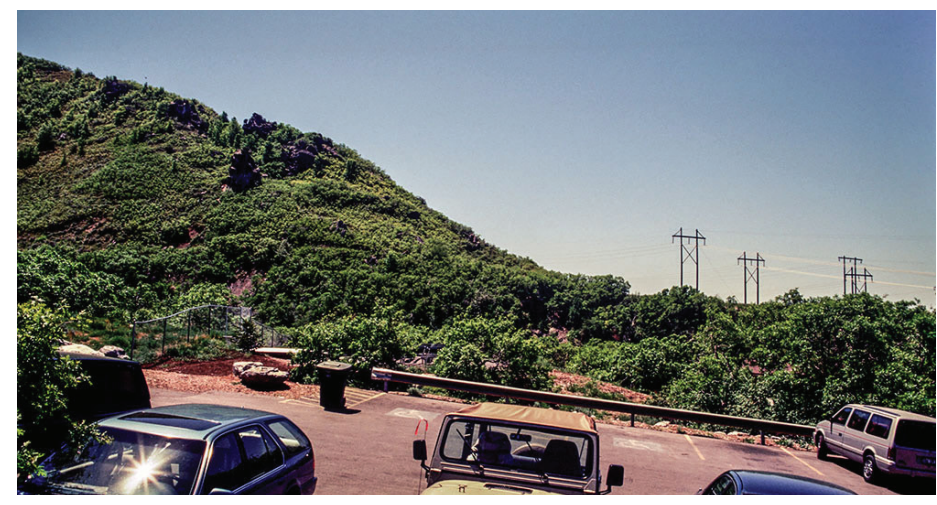

Figure 22. Looking south from the parking lot at the mouth of Rock Canyon. The power line poles are on the Bonneville terrace, a flat surface created when Lake Bonneville was at its highest level. The steep slope in the middle of the photo to the left of the power poles represents the approximate location of the Wasatch fault along which the mountains have been uplifted.

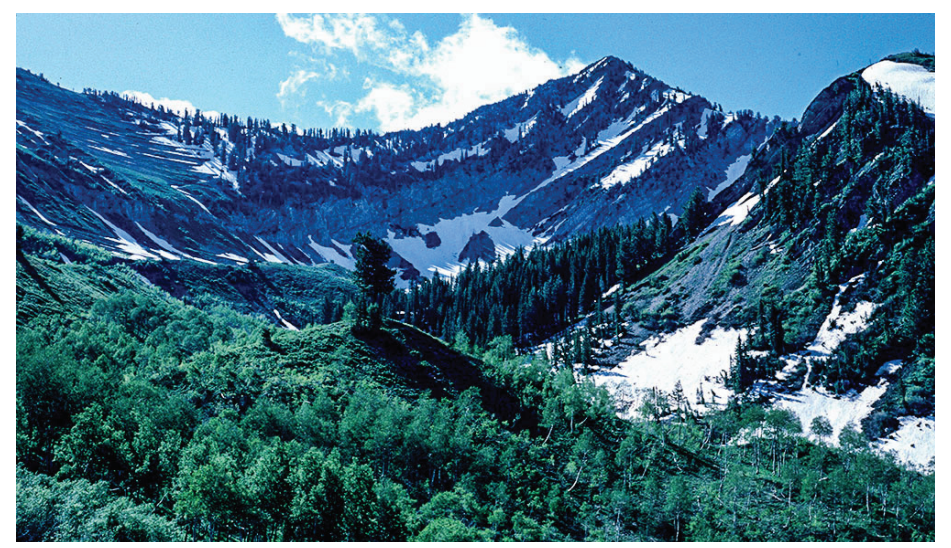

Figure 23. In the high elevations to the east, near the head of Rock Canyon, the canyon opens up into a wide "U" shape sculpted out by glaciers during the Pleistocene ice ages.

ter of the Church of Jesus Christ of Latter-day Saints are built on this alluvial fan. As described earlier in this paper, the alluvial fan is a place where flooding out of the canyon can still be a problem.

\section{SUMMARY}

Rock Canyon is a location where many of the events that shaped Utah's geologic history can be studied and observed. It is an excellent place for students, scout groups, families, or anyone interested in learning more about geology to spend a few hours. The hiking trails, picnic areas, rock climbing areas, rest rooms, along with easy access and parking make this one of Utah's best outdoor geologic laboratories.

\section{REFERENCES CITED}

Armstrong, R.L., 1968, Sevier orogenic belt in Nevada and Utah: Geological Society of America Bulletin, v. 79, p. 429-458. Atwood, W.W., 1909, Glaciation of the Uinta and Wasatch Mountains: U.S. Geological Survey Professional Paper 61.

Baker, A.A., 1972, Geologic map of the Bridal Veil Falls quadrangle, Utah: U.S. Geological Survey Map GQ-998 (1:24,000).
Baker, A.A., 1973, Geologic map of the Springville quadrangle, Utah: U.S. Geological Survey Map GQ-1103 (1:24,000).

Baker, A.A., Huddle, J.W., and Kinney, D.M., 1949, Paleozoic geology of north and west sides of Uinta Basin, Utah: Bulletin of the American Association of Petroleum Geologists, v. 33, p. 1161-1197.

Bissell, H.J., 1974, Tectonic control of Late Paleozoic and Early Mesozoic sedimentation near the hinge line of the Cordilleran miogeosynclinal belt: Tectonics and Sedimentation, the Society of Economic Paleontologists and Mineralogists, v. SP22, p. 83-97.

Blackwelder, E., 1931, Pleistocene glaciation in the Sierra Nevada and Basin Ranges: Geological Society of America Bulletin, v. 42, p. 865-922.

Bush, S., 1995, Rock Canyon watershed: A history and resource review: Honors Thesis, Brigham Young University, 53 p. (AS 36.B752 B8812 1995).

Christie-Blick, N., 1983, Glacial-marine and subglacial sedimentation Upper Proterozoic Mineral Fork Formation, Utah, in Molnia B.F., editor, Glacial-Marine Sedimentation: Springer, Boston, MA, p. 703-776.

Christie-Blick, N., 1997, Neoproterozoic sedimentation and tectonics in west-central Utah, in Link, P.K, and Kowallis, B.J., editors, Proterozoic to recent stratigraphy, tectonics, and volcanology, Utah, Nevada, southern Idaho and central Mexico: Brigham Young University Geology Studies, v. 42, part I, p. 1-30.

Clark, D.L., Derenthal, D., Kowallis, B.J., and Ritter, S.M., 2014, The major pre-Mississippian unconformity in Rock Canyon, central Wasatch Range, Utah: Geology of the Intermountain West, v. 1, p. 1-5.

Crittenden, M.D., Jr., Christie-Blick, N., and Link, P.K., 1983, Evidence for two pulses of glaciation during the late Proterozoic in northern Utah and southeastern Idaho: Geological Society of America Bulletin, v. 94, p. 437-450.

Davis, F.D., 1983, Geologic map of the southern Wasatch Front, Utah: Utah Geological and Mineral Survey Map 55-A $(1: 100,000)$.

DeCelles, P.G., and Coogan, J.C., 2006, Regional structure and kinematic history of the Sevier fold-and-thrust belt, central Utah: Geological Society of America Bulletin, v. 118, p. 841864.

Ersking, M.C., 1997, The Oquirrh Basin revisited: American Association of Petroleum Geologists Bulletin, v. 81, p. 624-636.

Gilbert, G.K., 1890, Lake Bonneville: U.S. Geological Survey Monograph 1, 438 p. 
Granger, A.E., Sharp, B.J., Crittenden, M.D., and Calkins, F.C., 1952, Geology of the Wasatch Mountains east of Salt Lake City: Utah Geological Society, Geology of the central Wasatch Mountains, Utah, Guidebook to the Geology of Utah, no. 8, p. $1-37$.

Hintze, L.F., 1978, Geologic map of the Y Mountain area, east of Provo, Utah: Brigham Young University Geology Studies, Special Publication 5.

Hintze, L.F., and Kowallis, B.J., 2009, Geologic History of Utah: Brigham Young University Geology Studies Special Publication 9, $225 \mathrm{p}$.

Jensen, J.M., 1924, Early History of Provo, Utah: Provo, Utah, self-published, available at Brigham Young University Harold B. Lee Library (F 834 .P8 J45x 1924), 182 p.

Jordan, T.E., and Douglass, R.C., 1980, Paleogeography and structural development of the Late Pennsylvanian to Early Permian Oquirrh Basin, northwestern Utah, in Fouch, T.D., and Magathan, E.R., editors, Paleozoic Paleogeography of west central United States: Society of Economic Paleontologists and Mineralogists, Rocky Mountain Section, West-Central United States Paleogeography Symposium I, p. 217-238.

Kay, M., 1951, North American geosynclines: Geological Society of America Memoir 48, 143 p.

Kluth, C.F., 1986, Plate Tectonics of the Ancestral Rocky Mountains: Part III, Middle Rocky Mountains: Paleotectonics and Sedimentation in the Rocky Mountain Region, United States: American Association of Petroleum Geologists Memoir 41, p. 353-369.

Kowallis, B.J., and Walker, B., 2009, Rock Canyon field guide: Brigham Young University Department of Geological Sciences, 1 folded sheet.

Kowallis, B.J., Ferguson, J., and Jorgensen, G.J., 1990, Uplift along the Salt Lake segment of the Wasatch fault from apatite and zircon fission track dating in the Little Cottonwood stock: Nuclear Tracks and Radiation Measurements, v. 17, p. 325-329.

Lee, W.T., 1918, Early Mesozoic physiography of the southern Rocky Mountains: Smithsonian Miscellaneous Collections, v. 69.

Link, P.K., Miller, J.M.G., and Christie-Blick, N., 1994, Glacial-marine facies in a continental rift environment: Neoproterozoic rocks of the western United States Cordillera, in Deynoux, M., Miller, J.M.G., Domack, E.W., Eyles, N., Fairchild, I.J., and Young, G.M., editors, Earth's Glacial Record: Cambridge University Press, p. 29-46.

Lochman-Balk, C., 1976, The Cambrian section of the central Wasatch Mountains, in Hill, J.G., editor, Geology of the Cordilleran Hingeline: Rocky Mountain Association of Geologists - 1976 symposium, p. 103-108.
Lund, W.R., 2005, Consensus preferred recurrence-interval and vertical slip-rate estimates: Review of Utah paleoseismic-trenching data by the Utah Quaternary Fault Parameters Working Group: Utah Geological Survey Bulletin 134, 109 p.

Lund, W.R., and Black, B.D., 1998, Paleoseismic investigation at Rock Canyon, Provo segment, Wasatch fault zone, Utah County, Utah: Utah Geological Survey Special Study 93, 21 p.

Machette, M.N., Personius, S.F., Nelson, A.R., Schwartz, D.P., and Lund, W.R., 1991, The Wasatch fault zone, Utah-segmentation and history of Holocene earthquakes: Journal of Structural Geology, v. 13, p. 137-149.

Madsen, D.B., and Currey, D. R., 1979, Late Quaternary glacial and vegetation changes, Little Cottonwood Canyon area, Wasatch Mountains, Utah: Quaternary Research, v. 12, p. 254-270.

Matsch, C.L., and Ojakangas, R.W., 1991, Comparisons in depositional style of "polar" and "temperate" glacial ice, Late Paleozoic Whiteout Conglomerate (West Antarctica) and late Proterozoic Mineral Fork Formation (Utah), in Anderson, J.B., and Ashley, G.M., editors, Glacial marine sedimentation: Paleoclimatic significance: Geological Society of America, Special Paper 261, p. 191-206.

Naeser, C.W., Bryant, B., Crittenden, M.D., Jr., and Sorensen, M.L., 1983, Fission-track ages of apatite in the Wasatch Mountains, Utah: an uplift study: Geological Society of America Memoir 157, p. 29-36.

Ojakangas, R.W., and Matsch, C.L., 1980, Upper Precambrian (Eocambrian) Mineral Fork Tillite of Utah: A continental glacial and glaciomarine sequence: Geological Society of America Bulletin, Part I, v. 91, p. 495-501.

Oviatt, C.G., 1997, Lake Bonneville fluctuations and global climate change: Geology, v. 25, p. 155-158.

Parry, W.T., and Bruhn, R.L., 1987, Fluid inclusion evidence for minimum $11 \mathrm{~km}$ vertical offset on the Wasatch fault, Utah: Geology, v. 15, p. 67-70.

Petersen, M.S., Rigby, J.K., and Hintze, L.F., 1973, Historical geology of North America: Dubuque, Iowa, Wm. C. Brown Co., 193 p.

Peterson, D.O., and Clark, D.L., 1974, Trace fossils Plagiogmus and Skolithos in the Tintic Quartzite (Middle Cambrian) of Utah: Journal of Paleontology, v. 48, p. 766-768.

Reheis, M.C., Adams, K.D., Oviatt, C.G., and Bacon, S.N., 2014, Pluvial lakes in the Great Basin of the western United States-a view from the outcrop: Quaternary Science Reviews, v. 97, p. 33-57.

Stokes, W.L., 1976, What is the Wasatch Line?, in Hill, J.G., editor, Geology of the Cordilleran Hingeline: Rocky Mountain Association of Geologists-1976 Symposium, p. 11-25. 
Varney, P.J., 1976, Depositional environment of the Mineral Fork Formation (Precambrian), Wasatch Mountains, Utah, in Hill, J.G., editor, Geology of the Cordilleran Hingeline, Rocky Mountain Association of Geologists - 1976 symposium, p. 91-102.

Ver Wiebe, W.A., 1930, Ancestral Rocky Mountains: American Association of Petroleum Geologists Bulletin, v. 14, p. 765788.

Wald, L.C., 2007, Structural analysis of Rock Canyon near Provo, Utah: M.S. thesis, Brigham Young University, 63 p.

Wilson, M.L., 1988, Analysis of a proposed economic development: The case of Heritage Mountain: M.S. Thesis, Brigham Young University, Provo, Utah, 123 p. (G1.02 .W55 1988).

Ye, H., Royden, L., Burchfiel, C., and Schuepbach, M., 1996, Late Paleozoic deformation of interior North America: the greater Ancestral Rocky Mountains: American Association of Petroleum Geologists Bulletin, v. 80, p. 1397-1432.

Young, R.G., 1966, Stratigraphy of coal-bearing rocks of Book Cliffs, Utah-Colorado: Utah Geological and Mineral Survey Bulletin 80, p. 7-22. 